GRASAS Y ACEITES 69 (3)

July-September 2018, e264

ISSN-L: 0017-3495

https://doi.org/10.3989/gya.0219181

\title{
Frying performance of olive-extracted oils
}

\author{
G. Márquez-Ruiz ${ }^{\bowtie}$ and F. Holgado \\ Instituto de Ciencia y Tecnología de Alimentos y Nutrición, Consejo Superior de Investigaciones Científicas (ICTAN-CSIC) \\ ${ }^{\square}$ Corresponding author: gmarquez@ictan.csic.es
}

Submitted: 08 February 2018; Accepted: 19 April 2018

SUMMARY: In this article, the main studies on frying performance of olive-extracted oils, namely, virgin olive oils, olive oils and olive-pomace oils, are reviewed and discussed in relation to other vegetable oils. Firstly, the most relevant compositional data of olive-extracted oils and commonly used vegetable oils are reported, including modified seed oils developed for frying uses. The influence of the degree of unsaturation and of the minor compounds with protective effect during frying are discussed, with special reference to tocopherols, other phenolic compounds, phytosterols and squalene. Results on comparative behavior of olive-extracted oils and other vegetable oils reflect that all olive-extracted oils show great stability to thermal oxidation and are highly suitable for frying, due to their high content of oleic acid, low content of polyunsaturated fatty acids and occurrence of minor components with antioxidant activity or protective effects. Among olive-extracted oils, the scarce information published on used frying pomace-olive oils is noted.

KEYWORDS: Frying; Olive oil; Olive-pomace oil; Virgin olive oil

RESUMEN: Comportamiento en fritura de los aceites extraídos de la aceituna. En este artículo se revisan los principales estudios sobre el comportamiento en fritura de los aceites extraídos de la aceituna, es decir, aceites de oliva virgen, de oliva y de orujo de oliva. En primer lugar se describe su composición, así como la de los aceites vegetales más utilizados y los aceites de semillas modificadas, y se comenta la influencia en fritura del grado de insaturación y de los componentes menores del aceite, especialmente tocoferoles, otros compuestos fenólicos, fitoesteroles y escualeno. Los estudios realizados en comparación con otros aceites vegetales reflejan la gran resistencia de los aceites extraídos de la aceituna a la oxidación térmica y su aptitud para la fritura, debido a sus altos contenidos en ácido oleico, bajos niveles de ácidos grasos poliinsaturados y presencia de componentes menores con actividad antioxidante o protectora. Entre los aceites extraídos de la aceituna, el comportamiento del aceite de orujo de oliva es el menos estudiado en fritura.

PALABRAS CLAVE: Aceite de oliva; Aceite de oliva virgen; Aceite de orujo de oliva; Fritura

ORCID ID: Márquez-Ruiz G https://orcid.org/0000-0002-8548-837X, Holgado F https://orcid.org/0000-0003-4950-5950

Citation/Cómo citar este artículo: Márquez-Ruiz G, Holgado F. 2018. Frying performance of olive-extracted oils. Grasas Aceites 69 (3), e264. https://doi.org/10.3989/gya.0219181

Copyright: (C2018 CSIC. This is an open-access article distributed under the terms of the Creative Commons Attribution 4.0 International (CC BY 4.0) License. 


\section{INTRODUCTION}

Frying is one of the most popular methods for the preparation of foods in developed countries, on a domestic as well as on industrial level. It is a complex process that involves a high number of reactions due to the action of oxygen, high temperature and the water released by the food, which lead to organoleptic changes, increase of viscosity, foaming, darkening and decrease of the smoke point. Although there are many methods to measure these changes, the only method that evaluates the total pool of non-volatile degradation compounds formed is the polar compounds determination. Hence it is an official method included in all the countries where frying oils are fully regulated and its limit is normally established at $25 \%$ polar compounds (Firestone, 2007). Determination of polymers, the main components of the polar compounds formed during frying, is also included in regulations of certain countries (Firestone, 2007).

Oil degradation during frying depends on the oil composition, namely, the degree of unsaturation, free fatty acidity and antioxidants/prooxidants contents, as well as on factors related to the process conditions, namely, the length of heating, temperature and surface-to-oil volume ratio, and on the nature and composition of the food being fried (MárquezRuiz et al., 2010). In discontinuous frying (domestic frying, frying in restaurants and fried-outlets), temperature, length of heating and the lack of protection of the oil by the food between frying operations greatly enhance alteration. It is essential to maintain the surface-to-volume ratio since its increase enhances the contact with air oxygen and thus oxidative reactions. However, in continuous frying (industrial frying), the food is constantly present in the fryer and oil is continuously replenished to compensate for that absorbed by food. In this case, the turnover period (time required for oil used to equal the oil in the fryer) is an essential factor and should be low $(<10-12 \mathrm{~h})$ to maintain oil high-quality in the long term.

The suitability of oil for frying is mostly related to its resistance to thermal oxidation, but price, availability and functional properties are also important factors for its selection. As mentioned above, the main variables associated to the oil influencing oxidation during frying are the degree of unsaturation and the content/nature of minor compounds with protective effects, and these will be discussed below with special focus on olive-extracted oils.

\section{CHARACTERIZATION OF OLIVE- EXTRACTED OILS AND MOST GLOBALLY USED OILS}

Table 1 lists the most relevant compositional data, including typical ranges, found for the olive-extracted oils (virgin, refined and refined olive-pomace) and the vegetable oils more generally used worldwide (Bockisch, 1998; Gunstone, 2002; Graciani, 2006; Erickson, 2007; White, 2008; García-González et al., 2013; Boskou, 2015). Extra virgin and virgin olive oils only differ in free acidity values from the chemical viewpoint and their compositions are within similar ranges, hence have been considered together in the table. Refined olive oil and refined olive-pomace oil are included but not the commercially available blends of refined olive oil with virgin olive oil and refined olive-pomace with virgin olive oil which composition in minor compounds may vary depending on the amount and composition of the virgin olive oil added. Besides main fatty acid composition, the most important minor unsaponifiable compounds, i.e., tocopherols, sterols and squalene, have been included. As can be observed, the ranges of concentrations reported are considerably broad in general, due to varietal differences, geographical location, soil type, climate, state of maturity and agricultural practices. As to production volume, palm oil, soybean oil, rapeseed/canola oil and sunflower oil are, in that order and by far, the most important oils in the world (Oil World Annual, 2017). But, apart for traditional oils, there are nowadays new types of vegetable oils obtained from genetically modified seeds and, also, many blends of oils are commercialized. These new oils and blends have the common objective of providing altered fatty acid patterns to improve unsaturation profile in nutritional terms and from the stability standpoint (Hosseini et al., 2016).

As shown in Table 1, all olive-extracted oils, including virgin olive oils, refined olive oils and refined olive-pomace oils, clearly stand out for their high content of oleic acid and low content of polyunsaturated fatty acids (linoleic and linolenic acids). Only palm oil shows even lower contents of polyunsaturated fatty acids. The great variability in fatty acid composition found among olive-extracted oils is not associated with categories but instead is the result of olive varietal differences and other factors (Boskou et al., 2006; García-González et al., 2013).

Regarding minor unsaponifiable compounds, amounts of squalene are much greater in all oliveextracted oils than in the rest of vegetable oils. And, among sterols, olive-extracted oils are primarily composed by $\beta$-sitosterol, and this only occurs also in cottonseed oil (Graciani, 2006; Boskou, 2015).

The refining process does not greatly affect the amounts and compositions of tocopherols and sterols (phytosterols) in olive-extracted oils. Thus, levels of tocopherols are similar for virgin olive oils, refined olive oils and refined olive-pomace oils. With respect to phytosterols, amounts are higher in refined olivepomace oils than in refined olive oils because such compounds are more abundant in crude olive-pomace oil than in crude olive oil (Antonopoulos et al., 2006). Also as a result of refining, the hydrocarbon fraction of phytosterols suffers certain changes, these 


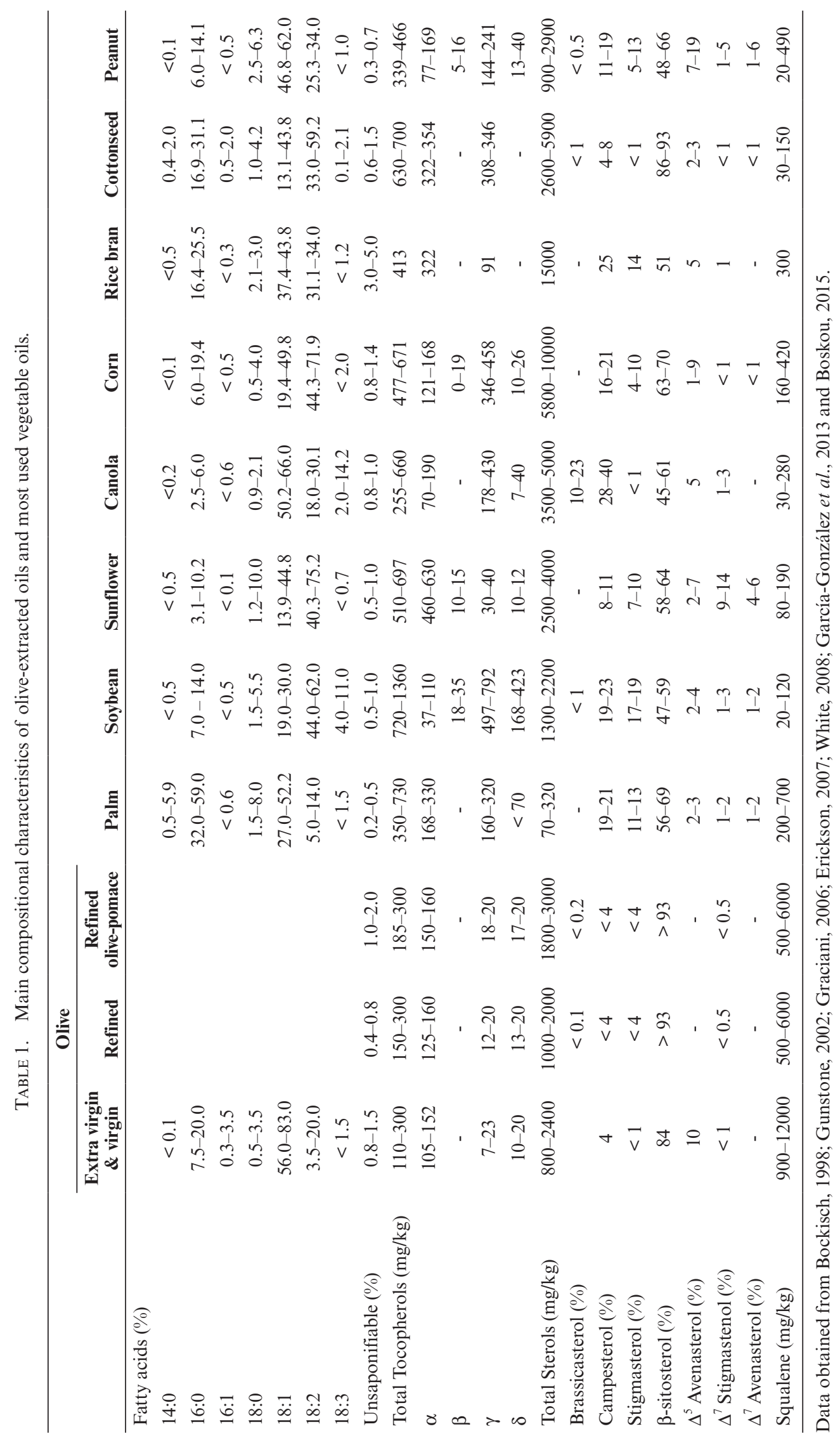


are, a considerable amount of squalene is removed and some new hydrocarbon derivatives are formed. Still, as commented before, amounts of squalene remaining in refined olive oil and refined pomaceolive oil are very high (Nergiz and Celikkale, 2011).

The refining process also removes polyphenols and triterpenic acids (Ruiz-Méndez et al., 2013). Contents of polyphenols are high in virgin olive oils although levels vary greatly $(200-800 \mathrm{mg} / \mathrm{kg})$, as well as in crude olive-pomace oil $(400-700 \mathrm{mg} / \mathrm{kg})$, are almost absent in refined olive oils and refined olive-pomace oils and found at about $400 \mathrm{mg} / \mathrm{kg}$ in commercial olive oils and about $150 \mathrm{mg} / \mathrm{kg}$ in commercial olive-pomace oils (García et al., 2003; 2006; Brenes et al., 2004), but these figures may vary depending on the amounts of phenolic compounds in the initial crude oils and in the virgin olive oils added. The most abundant phenolic compounds found in olive oils are secoiridoid derivatives (the dialdehydic form of decarboxymethyl ligstroside aglycone, the dialdehydic form of the decarboxymethyl oleuropein aglycone, the aldehydic form of oleuropein aglycone and the aldehydic form of ligstroside aglycone), lignans (pinoresinol and 1-acetoxypinoresinol), together with hydroxytyrosol and tyrosol formed by hydrolysis of their corresponding secoiridoid derivatives (Mateos et al., 2001).

In the case of crude olive-pomace oil, the longer the storage period of "alpeorujo" (the resulting by-product from two-phase extraction of olive oil), the higher the content of phenolic compounds in the oils extracted, reaching levels about $900 \mathrm{mg} / \mathrm{kg}$ in some oils extracted by second centrifugation. In such oils, the most relevant phenolic compounds are hydroxytyrosol, hydroxytyrosol acetate, tyrosol, catechol, 4-ethylphenol, vanillin and the lignans pinoresinol and 1-acetoxypinoresinol. However, lower amounts are present in olive-pomace oils extracted with hexane being hydroxytyrosol, its acetate and lignans the most representative (Brenes et al., 2004). 4-Ethylphenol is a volatile phenol with strong, unpleasant odor which is generally formed by microorganisms. It is present in crude olive-pomace oils in about $50 \mathrm{mg} / \mathrm{kg}$ but may reach very high concentrations (about $400 \mathrm{mg} / \mathrm{kg}$ ) in oils extracted by second centrifugation of "alpeorujo" stored for 8 months.

Although in very low amounts, there are some phenolic acids present in seed oils. Corn and cottonseed oils contain ferulic acid, as an ester of dihydro- $\beta$ sitosterol (about $6 \mathrm{mg} / \mathrm{kg}$ ) in the former. Cottonseed oil also contains trans-p-cumaric acid (present in peanut and soybean oils as well), $p$-hydroxybenzoic acid and trans-caffeic acid. Besides, canolol is present in canola oil. Nevertheless, it must be stressed that the phenolic content of seed oils is much lower than that in olive and olive-pomace oils (Colquhoun, 1996; Hidalgo et al., 2002).

As to triterpenic acids, only average amounts of $200-500 \mathrm{mg} / \mathrm{kg}$ are found in extra virgin and virgin olive oils while as much as $2000-10,000 \mathrm{mg} / \mathrm{kg}$ can be found in crude olive-pomace oils as a result of enrichment during storage of "alpeorujo" (PérezCamino and Cert, 1999; García et al., 2008; Ruiz-Méndez et al., 2013). Regarding the relative abundance of maslinic and oleanolic acids, it has been reported that both triterpenic acids can be extracted at high concentrations by means of centrifugation instead of solvent extraction with hexane (García et al., 2008). Since most of triterpenic acids are lost during refining (García et al., 2006), a new procedure of physical refining has been patented to obtain an edible oil with high concentration in triterpenic acids from olive-pomace oils obtained by centrifugation (Ruiz-Méndez et al., 2008).

Also as a consequence of the storage of "alpeorujo", crude olive-pomace oil is enriched in triterpenic alcohols (erythrodiol and uvaol), waxes and aliphatic fatty alcohols (García et al., 2008). These compounds are constituents of the fruit skin therefore higher concentrations are found in olive-pomace oil, especially after solvent extraction. In fact, erythrodiol and uvaol are normally used as markers for detection of olive-pomace oil in olive oils and are limited in olive oils in $4.5 \%$ of the sterol fraction. Aliphatic fatty alcohols increase during the storage of "alpeorujo" in large ponds, reaching amounts as high as $6000 \mathrm{mg} / \mathrm{kg}$ in crude olive-pomace oils. After refining, aliphatic alcohols also result from the hydrolysis of waxes that occurs in the saponification step. Ultimately, considerably high amounts of both groups of alcohols remain in refined olive-pomace oil (about $500 \mathrm{mg} / \mathrm{kg}$ of triterpenic alcohols and $2000-2500 \mathrm{mg} / \mathrm{kg}$ of aliphatic fatty alcohols), being always higher than those in refined olive oil (García et al., 2008).

\section{EFFECT OF DEGREE OF UNSATURATION OF OLIVE-EXTRACTED OILS ON FRYING}

Oils are mostly triacylglycerols (95-98\%) and the unsaturated allylic bonds of their esterified fatty acids are active sites that can react with oxygen, hence susceptibility to alteration during frying increases exponentially as the number of double bonds is higher. For the reaction with air oxygen, it is required that a hydrogen is removed from the carbon adjacent to the double bond in the fatty acid esterified in triacylglycerols and the strength of hydrogen-carbon bonds depends on their position respect to the double bond, what explains the great differences of oxidation rates of oleic (18:1), linoleic $(18: 2)$ and linolenic $(18: 3)$ acids. Stable frying oils usually require low linolenic acid $(<3 \%)$, increased oleic acid $(>40 \%)$ and decreased linoleic acid $(<50 \%)$ (Márquez-Ruiz et al., 2010). The excellent frying properties of virgin olive oils are well established and are in great part due to the high-oleic acid content (Chiou and Kalogeropoulos, 2017). As already 
commented, all oils derived from olives, including virgin olive oils, olive oils and olive-pomace oils, show similar fatty acid composition and variability found depends mostly on olive variety and other factors.

Hydrogenation and genetic modification are two of the processes intended to decrease the unsaturated fatty acids of frying oils. However, hydrogenation gives rise to undesirable trans fatty acids which occurrence in foods now requires its inclusion on the labels in many countries. Besides, hydrogenation produces metallic flavor and does not improve the quality of oils with low linolenic acid (Choe and Min, 2007).

Recently, a plethora of modified seed oils and oil mixtures have been proposed to achieve the desired balance of fatty acids, including high-oleic, highpalmitic and low-linoleic modified seed oils and mixtures of two, three and even four oils (canola, palm olein, corn oil and others) in different proportions (Gunstone, 2002; Hosseini et al., 2016). Some of these mixtures are labelled as "special oils intended for frying" and often contain the antifoaming additive dimethylpolysiloxane (DMPS).

Figure 1 includes, for comparative purposes, average values of fatty acids (FA) expressed as saturated FA, oleic acid (18:1), linoleic acid (18:2) and linolenic acid (18:3) in olive-extracted oils and in the main modified seed oils and oil blends commercialized or recently developed for frying uses (Gunstone, 2002; Graciani, 2006; Hosseini et al., 2016).
The oils coming from modified sunflower and canola (low-erucic rapeseed) seeds are widely commercialized in Europe and the United States. Among modified seed oils, high-oleic sunflower (HOSO) and high-oleic canola oils (HOCO) achieve very similar, high-oleic acid content to that of oliveextracted oils, although show slightly higher values of linolenic acid. However, other modified canola oils such as LLnCO (low-linolenic canola oil) and HOLLnCO (high-oleic low-linolenic canola oil) contain more linoleic acid (Hosseini et al., 2016). With lower costs than high-oleic sunflower oil and about $65 \%$ oleic acid, medium-oleic sunflower oil (MOSO) was commercialized in the United States with great success in 1998 (Gunstone, 2002). Medium-oleic canola oil (MOCO) shows similar fatty acid composition. More recently, high-oleic high-palmitic sunflower oil (HOHPSO), also with about $65 \%$ oleic acid, but with increased levels of palmitic acid (25\%) and only $2 \%$ linoleic acid, has shown excellent frying performance (Marmesat et al., 2005, 2008).

With respect to oil blends, although there are many others proposed (Hosseini et al., 2016), Figure 1 includes those most common. Mixtures generally contain palm olein, which is the liquid fraction obtained by fractionation of palm oil and has been largely used in industrial deep-frying because of its adequate fatty acid profile, i.e., $39-45 \%$ oleic acid, 10-13\% linoleic acid and linolenic acid lower than $1 \%$. In fact, palm olein is often used in binary

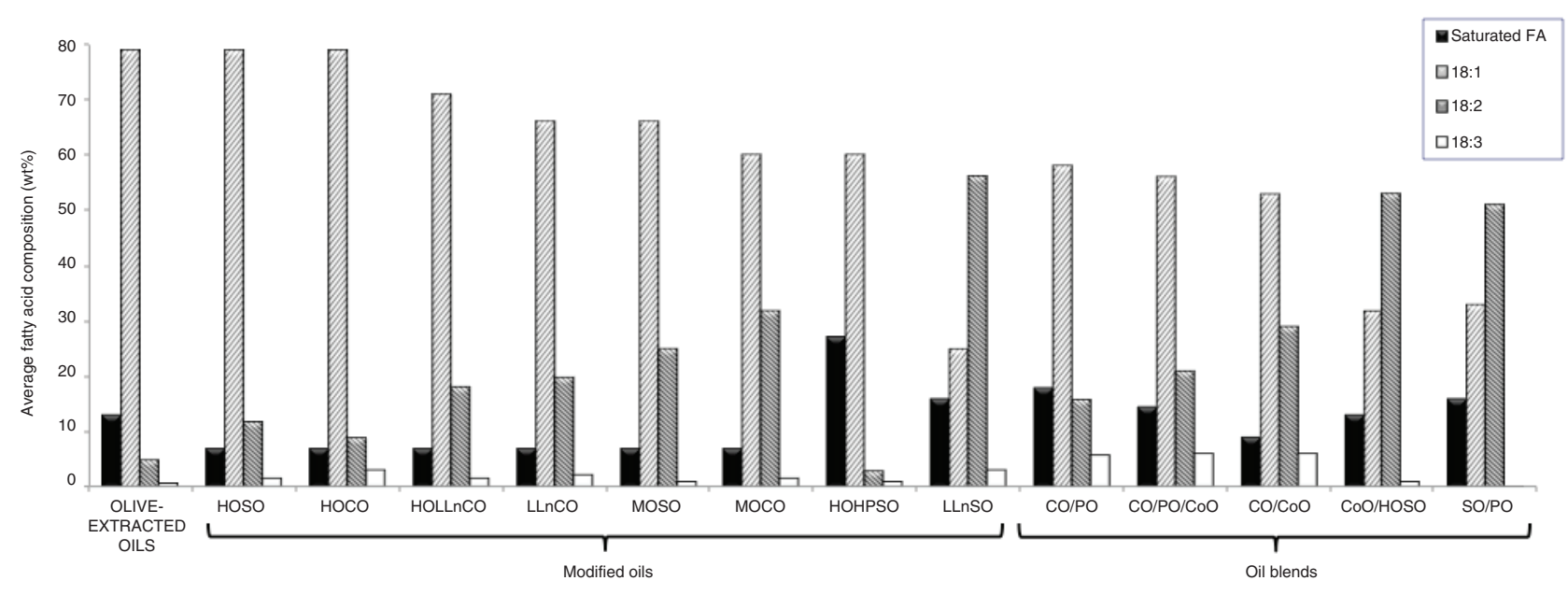

FIGURE 1. Average fatty acid composition expressed as saturated fatty acids (FA), oleic acid (18:1), linoleic acid (18:2) and linolenic acid (18:3) in olive-extracted oils, modified seed oils and oils blends.

Abbreviations: HOSO, high-oleic sunflower oil; HOCO, high-oleic canola oil; HOLLnCO, high-oleic low-linolenic canola oil; LLnCO, low-linolenic canola oil; MOSO, medium-oleic sunflower oil; MOCO, medium-oleic canola oil; HOHPSO, high-oleic high-palmitic sunflower oil; LLnSO, low-linolenic sunflower oil; CO/PO, canola oil/palm olein mixture; $\mathrm{CO} / \mathrm{PO} / \mathrm{CoO}$, canola oil/palm olein/corn oil mixture; $\mathrm{CO} / \mathrm{CoO}$, canola oil/corn oil mixture; $\mathrm{CoO} / \mathrm{HOSO}$, corn oil/high-oleic sunflower oil mixture; SO/PO, sunflower oil/palm olein mixture.

Data obtained from Gunstone, 2002; Graciani, 2006 and Hosseini et al., 2016 
blends with canola oil or sunflower oil and also in trinary blends (see mixtures canola oil/palm olein $(\mathrm{CO} / \mathrm{PO})$, canola oil/palm olein/corn oil $(\mathrm{CO} / \mathrm{PO} /$ $\mathrm{CoO}$ ) and sunflower oil/palm olein (SO/PO) in Figure 1). It is also worthy to note that some blends contain linoleic acid as major fatty acid (over $50 \%$ ), as corn oil/high-oleic sunflower oil (CoO/HOSO) and sunflower oil/palm olein (SO/PO), and still are commercialized as "special oils for frying".

The frying performance and stability depends on the overall composition of oil, including the unsaturation degree and the contribution of minor compounds with antioxidant action present in the unsaponifiable fraction. Therefore, the studies of interest on the effect of unsaturation degree evaluate the performance of oils from modified seeds with changed fatty acid composition as compared to that of their homologous, conventional oils therefore maintaining similar unsaponifiable fractions (Dobarganes et al., 1993; Normand et al., 2001; Guinda et al., 2003; Marmesat et al., 2008; Warner and Fehr, 2008). Results have commonly shown that the oil performs better as the degree of unsaturation is lower. Also, removal of tocopherols and other minor compounds stressed the great influence of the fatty acid composition (Lampi and Kamal Eldin, 1998; Barrera-Arellano et al., 2002; Steel et al., 2005, 2006).

\section{EFFECT OF MINOR COMPOUNDS PRESENT IN OLIVE-EXTRACTED OILS ON FRYING}

Many naturally occurring minor compounds in olive-extracted oils show antioxidant activity, and their capacity to protect oils under frying conditions has been discussed in recent reviews (MárquezRuiz et al., 2014; Aladedunye, 2014). Among them, four groups of compounds are of special relevance; namely, tocopherols, polyphenols, phytosterols and squalene.

\subsection{Tocopherols}

Tocopherols and tocotrienols constitute a family of natural, structurally related compounds which are also called globally vitamin E. Tocopherols are the main natural antioxidants occurring in edible oils and are also used as additives in frying oils to improve their oxidative stability. They constitute the lipophilic antioxidant group and mainly act as chain breakers by donating a hydrogen radical to the alkylperoxyl radicals formed during the propagation step of lipid oxidation, forming subsequently a stable radical. The tocopherol content of virgin olive oils is highly variety-dependent and usual values reported range between 100 and $300 \mathrm{mg} / \mathrm{kg}$ (Velasco et al., 2002). Once refined, tocopherols are partly lost hence amounts about $200 \mathrm{mg} / \mathrm{kg}$ are normally found in refined olive oil and refined olivepomace oil.

The loss of tocopherol at frying conditions is, in general, faster as the degree of oil unsaturation is lower (Yuki and Ishikawa, 1976; Jorge et al., 1996a, 1996b). However, the opposite is found at storage temperatures and even at about $100^{\circ} \mathrm{C}$, as in the accelerated tests used to evaluate oxidative stability (Yuki and Ishikawa, 1976; Martín-Polvillo et al., 2004; Márquez-Ruiz et al., 2008). These studies demonstrate that a mechanism dependent on temperature is involved in their action and an important practical consequence from this fact is that oxidative stability values obtained in Rancimat, normally at $100-120^{\circ} \mathrm{C}$, are not indicative of the stability during frying. However, a method using the Rancimat apparatus that allows estimating the comparative stability of oils in frying has been proposed (Barrera-Arellano et al., 1997; Márquez-Ruiz et al., 2014). Briefly, conditions established are temperature set at $180^{\circ} \mathrm{C}$, no air bubbling, oil samples in tubes at a surface-to-oil volume ratio close to that in domestic frying and analysis of polar compounds or polymers after $10-15$ hours.

Another interesting conclusion on tocopherols efficacy in frying obtained in experiments using different oils is that tocopherols are exhausted in monounsaturated oils at lower oil degradations (Barrera-Arellano et al., 2002; Verleyen et al., 2002). When monounsaturated oils only have tocopherols as antioxidants, as occurs in most vegetable oils except for olive-extracted oils, and become unprotected at polar compounds levels much lower than the limit established in official regulations, the resulting fried products maintain good quality but may be more susceptible to oxidation during commercialization and storage (Márquez-Ruiz et al., 1999). This is an important aspect often ignored, which would be advantageous for olive-extracted oils in terms of frying since they contain additional minor compounds with protective effects such as polyphenols, phytosterols and squalene.

With respect to the relative stability of the different forms of tocopherol at frying temperature, there is general agreement that $\delta$-tocopherol is more stable than $\alpha$-tocopherol, whereas $\beta$ - and $\gamma$-tocopherols degrade at an intermediate rate (Barrera Arellano et al., 2002; Warner and Moser, 2009). As a result, new sunflower lines have been developed to increase levels of $\gamma$-tocopherol as the major natural antioxidant instead of the $\alpha$-tocopherol characteristic of the standard sunflower oil (Velasco et al., 2004). In particular, a modified sunflower seed oil with increased levels of oleic acid and palmitic acid, and enhanced proportion of $\gamma$-tocopherol ( $>95 \%$ of the total tocopherols) has been found highly stable at frying temperatures (Marmesat et al., 2008). 


\subsection{Phenolic compounds/Polyphenols}

Phenolic compounds (others than tocopherols) and polyphenols act as primary antioxidants by similar mechanism of action to that of tocopherols and constitute the hydrophilic antioxidant group. They are present in significant amounts only in virgin oils since they are practically lost during refining. The pool of phenolic compounds in virgin olive oils is composed by several classes, namely; phenolic acids (hydroxybenzoic and hydroxycinnamic acid derivatives), phenylethyl alcohols (tyrosol and hydroxytyrosol), flavonoids (apigenin, luteolin), lignans (pinoresinol and 1-acetoxypinoresinol) and secoiridoids (Bendini et al., 2007). Total phenolic compounds in virgin olive oils are highly variable, ranging from 100 to $800 \mathrm{mg} / \mathrm{kg}$ (Visioli et al., 1998; Kalogeropoulos and Tsimidou 2014; Boskou, 2015). Mean values of $500 \mathrm{mg} / \mathrm{kg}$ (Montedoro et al., 1992), or levels between 50 and $200 \mathrm{mg} / \mathrm{kg}$ (Boskou et al., 2006) have been reported. Such phenolic compounds are partly responsible for the improved frying stability reported for olive oils and their blends with conventional oils such as sunflower and canola oils (Casal et al., 2010; Abdel-Razek et al., 2011).

As already commented, amounts of phenolic compounds are higher in crude olive-pomace oils obtained by second centrifugation than in those extracted with hexane, being hydroxytyrosol, hydroxytyrosol acetate and pinoresinol found in similarly higher amounts than catechol, tyrosol and 1-acetoxypinoresinol (Brenes et al., 2004). The complete refining process of crude olive oil and crude olive-pomace oil removes most polyphenols and therefore those present in commercial olive oil and olive-pomace oil come mostly from the virgin olive oil present in the blends (García et al., 2003, 2006).

There are a large number of interesting studies focused on the relative or synergic effect of polyphenols and tocopherols. Analyses of the losses of tocopherols and polyphenols during frying have reported the highest rate of degradation for hydroxytyrosol and its derivatives, similar or intermediate rates for $\alpha$-tocopherol and lowest degradation rates for tyrosol, its derivatives and lignans (Andrikopoulos et al., 2002; Brenes et al., 2002; Gómez-Alonso et al., 2003; Nissiotis and Tasioula-Margari, 2003; Allouche et al., 2007; Daskalaki et al., 2009). As commented before, since $\alpha$-tocopherol undergoes the fastest degradation among the tocopherol homologues, it is considered the least active tocopherol in frying. However, hydroxytyrosol and its derivatives, the most efficient antioxidants in olive oils, are lost even more rapidly than $\alpha$-tocopherol during frying. Hence, the protection conferred by phenolic compounds in olive oils can be otherwise attributable to those with less antioxidant activity but more stable at frying temperatures, namely, lignans and tyrosol and its derivatives.

Extracts obtained from olive oils or their byproducts are often added to oils then commercialized as special oils (Kochhar, 2000; 2001; Gertz, 2004; Esposto et al., 2015). Apart from the positive effect in frying, the interest on phenolic compounds is focused on promoting the intake of such healthpromoting compounds through consumption of fried foods (Farag et al., 2007; Chiou et al., 2009; Jiménez et al., 2017).

\subsection{Phytosterols}

Phytosterols are the major constituents of the unsaponifiable fraction of edible oils. In oliveextracted oils, total phytosterols are higher in refined oils than in crude oils, and among refined olive oils, olive-pomace oils show the highest level, over $1800 \mathrm{mg} / \mathrm{kg}$. In all olive oils, $\beta$-sitosterol is by far the most abundant phytosterol ( $>93 \%$ ), followed by campesterol, $\Delta 7$-stigmastenol, stigmasterol and brassicasterol (Table 1). Whereas phytosterols offer no protection under the low and moderate temperatures of commercialization and storage conditions, they have been reported to improve the frying stability of oils (Sims et al., 1972; Gordon and Magos, 1983; Singh, 2013).

At first, antioxidant activity was exclusively attributed to the presence of an ethylidene side chain, as occurs in $\Delta 5$-avenasterol, $\Delta 7$-avenasterol, fucosterol, vernosterol and citrostadienol. Such phytosterols were considered antipolymerization agents even though they seemed to act as antioxidants considering their mechanism of action, i.e., formation of allyl radicals in a primary carbon atom followed by isomerization to a relatively stable tertiary radical (Gordon and Magos, 1983).

Later, inconsistent results were reported. Lampi and coworkers (1999) did not find any polymerization inhibition in high-oleic sunflower oil triacylglycerols added with $0.1 \%$ of fucosterol and neither did Wrinkler and Warner (2008) adding 0.05\% fucosterol to oils. In contrast, a slight protective effect was found for sterols with 2 and 3 double bonds containing or not the ethylidene side chain. Other studies on phytosterols devoid of the ethylidene group, such as $\beta$-sitosterol, suggest that alternative mechanisms may account for the protective effects of phytosterols under frying conditions (Kochhar and Gertz, 2004; Wrinkler and Warner, 2008).

In an interesting study, Singh (2013) examined the effect of $\beta$-sitosterol at 1,2 and $5 \%$ in model triacylglycerols and various oils during frying. Results clearly demonstrated that the presence of enhanced levels of $\beta$-sitosterol significantly decreased polymer formation in all samples. Acid-catalyzed conversion of sterols into steradienes at frying temperatures was suggested as a possible mechanism. Evidence of 
the fact that the conjugated diene system of steradiene played a prominent role in limiting polymers formation in frying oils was obtained by comparing the effect of sitosterol and sitostanol. The inefficiency of sitostanol was attributed to the absence of a double bond in the $\mathrm{C} 5$ position and hence inability to generate a conjugated diene system.

It is also interesting to comment that the stability of phytosterols during frying depends on the oil degree of unsaturation, similarly as it was found for tocopherols. Thus, the loss of phytosterols was higher in high-oleic sunflower oil than in soybean oil, even though oil degradation was significantly higher for the latter (Wrinkler and Warner, 2008).

\subsection{Squalene}

Squalene is a highly unsaturated triterpene hydrocarbon widely distributed in vegetable oils, with olive-extracted oils containing the highest amounts, up to $40 \%$ of the unsaponifiable fraction (Table 1). In fact, one of the most important differences between olive-extracted oils and other vegetable oils is the amount of squalene. Its concentration in olive-extracted oils varies between 0.22 and $0.7 \%$, whereas the range is as low as $0.002-0.03 \%$ in other edible vegetable oils (Graciani, 2006).

Nergiz and Celikkale (2011) evaluated the effect of the oil refining steps on the squalene content and found that, for a certain virgin olive oil containing $491 \mathrm{mg} / 100 \mathrm{~g}$, considerable levels remained after refining $(290 \mathrm{mg} / 100 \mathrm{~g})$. While the antioxidant activity of squalene under food storage conditions remains controversial, it is generally agreed that squalene inhibits thermoxidative degradation of oils under frying conditions (Gertz et al., 2000; Sims et al., 1972; Malecka, 1991, 1994). Apparently, this is due to the combined mode of action of $\alpha$-tocopherol and squalene as chain-breaking antioxidants. It has been suggested that $\alpha$-tocopherol could be regenerated from the tocopheroxyl radical by squalene (Manzi et al., 1998).

In an interesting study, squalene has been reported to be rather stable during frying. Specifically, its retention in seed oils and fats used for frying in restaurants remained over $50 \%$ even after $30 \mathrm{~h}$ of frying while a high recovery $(84-96 \%)$ was observed during the domestic deep-frying of potatoes in virgin olive oils (Kalogeropoulos and Andrikopoulos, 2004).

\section{FRYING PERFORMANCE OF OLIVE-EXTRACTED OILS}

Virgin olive oil is highly resistant to alteration during frying mainly due to two reasons; firstly, its fatty acid composition is characterized by a high monounsaturated-to-polyunsaturated fatty acid ratio and secondly, it contains a pool of minor compounds with powerful antioxidant activity, among which phenolic compounds stand out (Boskou, 2011; Chiou and Kalogeropoulos, 2017). It shows however lower smoke point as compared to refined oils.

As commented before, polyphenols are eliminated or drastically reduced during the refining process of all crude olive oils, thus are practically absent in refined olive oil and refined olive-pomace oil. However, other minor components which increase oil stability remain (squalene) or even increase (phytosterols) after refining. Once the refined olive oil and the refined olive-pomace oils are mixed with small amounts of virgin olive oils to obtain the commercial olive oil and olive-pomace oil, contribution of phenolic compounds slightly increases. Ultimately, both blends may show, even within the same class, very different composition of minor antioxidant compounds but maintain the fatty acid criteria for stable, healthful frying oils, i.e., low contribution of saturated and polyunsaturated fatty acids, very low contribution of linoleic acid and practically absence of trans fatty acids.

When virgin olive oils have been compared to sunflower oils and soybean oils, frying behaviour has always been, as expected, much better for the former. This is because the protective effect of low unsaturation degree and antioxidant action of polyphenols and other minor compounds in virgin olive oils surpasses largely that of tocopherols, otherwise much more abundant in seed oils (Valdés and García, 2006; Akil et al., 2015; Kalogianni et al., 2017; MolinaGarcía et al., 2017; Santos et al., 2018). Virgin olive oils have also shown better results than high-oleic sunflower oils, even though they both contain high levels of oleic acid (Romero et al., 1999; SánchezGimeno et al., 2009). However, frying behaviour of virgin olive oils depends considerably on the olive variety (Abenoza et al., 2016) and on the olive ripening degree (Olivero-David et al., 2014; 2017).

Refined olive oils are also more stable than refined unsaturated seed oils, for example, soybean oil, sunflower oil and corn oil (Zribi et al., 2014; Santos et al., 2017) and even slightly more stable than palm olein, this latter being much more saturated because of its high content (36-39\%) of palmitic acid (Tabee et al., 2009; Romano et al., 2012). In the study by Zibri et al., (2014), this finding was in part attributed to the higher amounts of polyphenols remaining after refining in the case of refined olive oil $(85 \mathrm{mg} / \mathrm{kg})$ as compared to refined seed oils $(15-10 \mathrm{mg} / \mathrm{kg})$. However, in the study which compared refined olive oil with palm olein the almost 3-times higher content of sterols in the former was suggested to be the main responsible for the significantly better frying performance of refined olive oil (Tabee et al., 2009).

However, the most interesting comparison was made between the commercially available olive oils and high-oleic sunflower oils (Dobarganes et al., 1993; Barrera-Arellano et al., 2002). Original oils 
showed much better results for olive oil but once stripped of antioxidants, both oils behaved similarly. This demonstrates that differences in palmitic and linoleic acids between the oils did not have an influence on frying stability. When antioxidantstripped oils were added with $500 \mathrm{mg} / \mathrm{kg}$ tocopherols, approximately the content in the original high-oleic sunflower oil, stability of olive oils was similar to that of high-oleic sunflower oil and much lower than in the initial oil. Taking into account that initial olive oils had only $200 \mathrm{mg} / \mathrm{kg}$ tocopherols, these results demonstrated the considerable protective effect of antioxidants other than tocopherols present in olive oils.

As to the comparative behaviour of commercially available virgin olive oil and olive oil in frying, Casal et al., (2010) found similar results for extra virgin olive oil, virgin olive oil and olive oil in domestic frying, not attributable to the variable amounts of tocopherols and phenols. Therefore, from the stability point of view, virgin olive oils do not seem to provide additional protection than the commercially available olive oil. In other words, higher concentrations of minor compounds with protective action in virgin olive oils as compared to those in olive oil appear not to enhance frying stability. Suffice to say, however, that variations between all these classes of olive oils in minor compounds not only with antioxidant action but also with prooxidant activity can give rise to different comparative frying behaviour.

Regarding olive-pomace oil, studies published on frying are very limited. Chantzos et al., (2007) included olive-pomace oil in a study directed to propose an alternative approach for monitoring oils at different temperatures through radical scavenging assays. Unfortunately, only peroxide values and $p$-anisidine values, exclusively recommended to monitor oxidation at room and moderate temperatures, were provided as measurements of oil alteration. Results seemed to indicate that olive-pomace oil and extra virgin olive oil showed similar and better stability at frying temperatures as compared to the rest of oils.

The study carried out by Tekin et al., (2009) compared hazelnut, olive-pomace, grapeseed and sunflower oils during frying and found satisfactory performance of hazelnut and olive-pomace oils, even though content of oleic acid was higher and total unsaturation degree lower in hazelnut oil. As to minor compounds, even when tocopherols were lacking in olive-pomace oil and present at 250-500 $\mathrm{mg} / \mathrm{kg}$ in hazelnut oil, the presence of other minor compounds not described in the compositional data could have been accounted for the good performance of olive-pomace oil. In another work, the same research group (Bulut and Yilmaz, 2010) reported that formation of polar compounds during frying was higher in sunflower oil samples than in refined olive-pomace oil samples. Contents of minor compounds which can have influence on oil frying performance were not analyzed either, but results obtained were those expected from the comparatively higher degree of unsaturation of sunflower oil.

\section{CONCLUSIONS}

All olive-extracted oils, including virgin olive oils, commercialized olive oils (blends of refined olive oil and small amount of virgin olive oil) and commercialized olive-pomace oils (blends of refined olivepomace oil and small amount of virgin olive oils), stand out for their high content of oleic acid and low content of polyunsaturated fatty acids (linoleic and linolenic acids), thereby their great stability to thermal oxidation and suitability for frying. Besides, olive-extracted oils possess naturally occurring minor components with antioxidant activity or protective effects under frying conditions, such as phenolic compounds, phytosterols and squalene. Studies carried out on different classes of olive-extracted oils have shown their excellent frying behaviour but among these, olive-pomace oils have been scarcely studied so far. Some discrepancies shown in the literature regarding comparative behaviour of olivepomace oil with other vegetable oils is due to the variable relative contents and synergic action of protective compounds often not reported.

\section{ACKNOWLEDGMENTS}

The authors thank the Spanish Ministry of Economy, Industry and Competitiveness (Project SAFEFRYING AGL2015-64234-R) and ORIVA (Interprofesional del Aceite de Orujo de Oliva) for financial support.

\section{REFERENCES}

Abenoza M, Heras P de las, Benito M, Oria R, Sánchez-Gimeno AC. 2016. Changes in the physicochemical and nutritional parameters of Piqual and Arbequina olive oils during frying. J. Food Process Preserv. 40, 353-61. https://doi.org/ $10.1111 /$ jfpp. 12612

Abdel-Razek AG, El-Shami SM, El-Mallah MH, Hassainen MMM. 2011. Blending of virgin olive oil with less stable edible oils to strengthen their antioxidative potencies. Aust. J. Basis App. Sci. 5, 312-318.

Akil E, Castelo Branco V, Magalhães, Amaral Vendramini AL, Calado V, Guedes Torres A. 2015. Oxidative stability and changes in chemical composition of extra virgin olive oils after short-term deep-frying of French fries. J. Am. Oil Chem. Soc. 92, 409-421. https://doi.org/10.1007/ s11746-015-2599-2

Aladedunye F. 2014. Natural antioxidants as stabilizers of frying oils. Eur. J. Lipid Sci. Technol. 116, 688-706. https://doi. org/10.1002/ejlt.201300267

Allouche Y, Jiménez A, Gaforio JJ, Uceda M, Beltrán G. 2007. How heating affects extra virgin olive oil quality indexes and chemical composition. J. Agric. Food Chem. 55, 964654. https://doi.org/10.1021/jf070628u

Andrikopoulos NK, Dedoussis GVZ, Falirea A, Kalogeropoulos N, Hatzinikola HS. 2002. Deterioration of natural antioxidant species of vegetable edible oils 
during the domestic deep-frying and pan-frying of potatoes. Int. J. Food Sci. Nutr. 53, 351-363. https://doi. org/10.1080/09637480220138098

Antonopoulos K, Valet N, Spiratos D, Siragakis G. 2006. Olive oil and pomace olive oil processing. Grasas Aceites 57, 56-67. https://doi.org/10.3989/gya.2006.v57.i1.22

Barrera-Arellano D, Márquez-Ruiz G, Dobarganes MC. 1997. A simple procedure to evaluate the performance of fats and oils at frying temperatures. Grasas Aceites 48, 231-235. https://doi.org/10.3989/gya.1997.v48.i4.794

Barrera-Arellano D, Ruiz-Méndez MV, Velasco J, MárquezRuiz G, Dobarganes MC. 2002. Loss of tocopherols and formation of degradation compounds at frying temperatures in oils differing in unsaturation degree and natural antioxidant content. J. Sci. Food Agric. 82, 1696-1702. https://doi.org/10.1002/jsfa.1245

Bendini A, Cerretani L, Carrasco-Pancorbo A, Gómez-Caravaca A, Segura-Carretero A, Fernández-Gutiérrez A, Lercker G. 2007. Phenolic molecules in virgin olive oils: a survey of their sensory properties, health effects, antioxidant activity and analytical methods. An overview of the last decade. Molecules 12, 1679-1719. https://doi.org/10.3390/12081679

Bockisch M. 1998. Vegetable Fats and Oils, in Fats and Oils Handbook. Ed. Bockisch M, AOCS Press, Champaign, IL, 174-344.

Boskou D. 2011. Non-nutrient antioxidants and stability of frying oils, in Frying of Foods: Oxidation, Nutrient and Nonnutrient Antioxidants, Biologically Active Compounds and High Temperatures. Eds. Boskou D, Elmadfa I, Taylor and Francis Group, Boca Raton, FL, 199-223.

Boskou D. 2015. Olive fruit, table olives, and olive oil bioactive constituents, in Olive and Olive Oil Bioactive Constituents. Ed. Boskou D, AOCS Press, Urbana, IL, 1-30.

Boskou D, Tsimidou M, Blekas D. 2006. Olive oil composition, in Olive Oil Chemistry and Technology $2^{\text {nd }}$ Edition. Ed. Boskou D, AOCS Press, Champaign, IL, 41-72.

Brenes M, García A, Dobarganes MC, Velasco J, Romero C. 2002. Influence of thermal treatments simulating cooking processes on the polyphenol content of virgin olive oil. $J$. Agric. Food Chem. 50, 5962-5967. https://doi.org/10.1021/ jf020506w

Brenes M, Romero C, García A, Hidalgo FJ, Ruiz-Méndez MV. 2004. Phenolic compounds in olive oils intended for refining: formation of 4-ethylphenol during olive paste storage. J. Agric. Food Chem. 52, 8177-8181. https://doi.org/ $10.1021 / \mathrm{jf} 0402532$

Bulut E, Yilmaz E. 2010. Comparison of the frying stability of sunflower and refined olive pomace oils with/without adsorbent treatment. J. Am. Oil Chem. Soc. 87, 1145-1153. https://doi.org/10.1007/s11746-010-1605-y

Casal S, Malheiro R, Sendas A, Oliveira B, Pereira JA. 2010. Olive oil stability under deep-frying conditions. Food Chem. Toxicol. 48, 2972-2979. https://doi.org/10.1016/j.fct. 2010.07 .036

Chantzos NV, Georgiou CA. 2007. Monitoring lipid oxidation events at frying temperatures through radical scavenging assays. Chem. Ind. Chem. Eng. Quart. 13, 163-166. https:// doi.org/10.2298/CICEQ0703163C

Chiou A, Kalogeropoulos N. 2017. Virgin olive oil as frying oil. Comp. Rev. Food Sci. Food Safety 16, 632-646. https://doi. org/10.1111/1541-4337.12268

Chiou A, Kalogeropoulos N, Salta FN, Efstathiou P, Andrikopoulos NK. 2009. Pan-frying of French fries in three different edible oils enriched with olive leaf extract: Oxidative stability and fate of microconstituents. $L W T$ Food Sci. Technol. 42, 1090-1097. https://doi.org/10.1016/j. lwt.2009.01.004

Choe E, Min DB. 2007. Chemistry of deep-fat frying oils. J. Food Sci.72, R77-R86. https://doi.org/10.1111/j.1750-3841.2007. $00352 . x$

Colquhoun DM. 1996. Phenolic content of olive oil is reduced in extraction and refining: Analysis of phenolic content of three grades of olive and ten seed oils. Asia Pac. J. Clin. Nut. 5, 105-107.

Daskalaki D, Kefi G, Kotsiou K, Tasioula-Margari M. 2009. Evaluation of phenolic compound degradation in virgin olive oil during storage and heating. J. Food Nutr. Res. 48, 31-41.

Dobarganes MC, Márquez-Ruiz G, Pérez-Camino MC. 1993. Thermal stability and frying performance of genetically modified sunflower seed (Helianthus annuus L.) oils. J. Agric. Food Chem. 41, 678-681. https://doi.org/10.1021/ jf00028a033

Erickson DR. 2007. Production and composition of frying fats, in Deep Frying: Chemistry, Nutrition and Practical Applications. Ed. Erickson MD, AOCS Press, Champaign, US, 3-24.

Esposto S, Taticchi A, Di Maio I, Urbani S, Veneziani G, Selvaggini R, Sordini B, Servili M. 2015. Effect of an olive phenolic extract on the quality of vegetable oils during frying. Food Chem. 176, 184-192. https://doi.org/10.1016/j. foodchem.2014.12.036

Farag RS, Mahmoud EA, Basuni AM. 2007. Use crude olive leaf juice as a natural antioxidant for the stability of sunflower oil during heating. Int. J. Food Sci. Technol. 42, 107-115. https://doi.org/10.1111/j.1365-2621.2006.01374.x

Firestone D. 2007. Regulation of frying fats and oils, in Deep Frying: Chemistry, Nutrition and Practical Applications. Ed. Erickson MD, AOCS Press, Champaign, US, 373-385.

García A, Brenes M, Dobarganes MC, Romero C, Ruiz-Méndez MV. 2008. Enrichment of pomace oil in triterpenic acids during storage of "Alperujo" olive paste. Eur. J. Lipid Sci. Technol. 110, 1136-1141. https://doi.org/10.1002/ejlt. 200800070

García A, Brenes M, García P, Romero C, Garrido A. 2003. Phenolic content of commercial olive oils. Eur. Food Res. Technol. 216, 520-525. https://doi.org/10.1007/ s00217-003-0706-3

García A, Ruiz-Méndez MV, Romero C, Brenes M. 2006. Effect of refining on the phenolic composition of crude olive oils. J. Am. Oil Chem. Soc. 83, 159-164. https://doi.org/10.1007/ s11746-006-1189-8

García-González DL, Infante-Domínguez C, Aparicio R. 2013. Tables of olive oil chemical data, in Handbook of Olive Oil: Analysis and Properties. Ed. Aparicio R, Harwood J, Springer, US, 739-768. https://doi.org/10.1007/ 978-1-4614-7777-8

Gertz C. 2000. Chemical and physical parameters as quality indicators of used frying fats. Eur. J. Lipid Sci. Technol. 102, 566-572. https://doi.org/10.1002/1438-9312 (200009) 102:8/9<566::AID-EJLT566>3.0.CO;2-B

Gertz C. 2004. Optimising the baking and frying process using oil-improving agents. Eur. J. Lipid Sci. Technol. 106, 736-745. https://doi.org/10.1002/ejlt.200401015

Gómez-Alonso S, Fregapane G, Salvador MD, Gordon MH. 2003. Changes in phenolic composition and antioxidants activity of virgin olive oil during frying. J. Agric. Food Chem. 51, 667-672. https://doi.org/10.1021/jf025932w

Gordon MH, Magos P. 1983. The effects of sterols on the oxidation of edible oils. Food Chem. 10, 141-147. https://doi. org/10.1016/0308-8146(83)90030-4

Graciani Constante E. 2006. Componentes de los aceites y/o grasas y compuestos relacionados, in Los Aceites y Grasas: composición y propiedades. Ed. Graciani Constante E, Madrid Vicente ed y Ed. Mundi, Madrid, España, 11-118.

Guinda A, Dobarganes MC, Ruiz MV, Mancha M. 2003. Chemical and physical properties of a sunflower oil with high levels of oleic and palmitic acids. Eur. J. Lipid Sci. Technol. 105, 130-137. https://doi.org/10.1002/ejlt.200390028

Gunstone F. 2002. Vegetable Oils in Food Technology: Composition, Properties and Uses. Ed. Gunstone F, Blackwell Publishing, Oxford, UK.

Hidalgo FJ, Gómez G, Navarro JL, Zamora R. 2002. Oil stability prediction by high-resolution ${ }^{13} \mathrm{C}$ nuclear magnetic resonance spectroscopy. J. Agric. Food Chem. 50, 5825-5831. https://doi.org/10.1021/jf0256539

Hosseini H, Ghorbani M, Meshginfar N, Mahoonak AS. 2016. A review on frying: procedure, fat, deterioration progress and health hazards. J. Am. Oil Chem. Soc. 93, 445-466. https://doi.org/10.1007/s11746-016-2791-z

Jorge N, Márquez-Ruiz G, Martín-Polvillo M, Ruiz-Méndez MV, Dobarganes MC. 1996a. Influence of dimethylpolysiloxane 
addition to edible oils: dependence on the main variables of the frying process. Grasas Aceites 47, 14-19. https://doi. org/10.3989/gya.1996.v47.i1-2.837

Jorge N, Márquez-Ruiz G, Martín-Polvillo M, Ruiz-Méndez MV, Dobarganes MC. 1996b. Influence dimethylpolyxilosane addition to frying oils: Performance of sunflower oils in discontinuous and continuous laboratory frying. Grasas Aceites 47, 20-25. https://doi.org/10.3989/gya.1996.v47. i1-2.838

Jiménez P, García P, Bustamante A, Barriga A, Robert P. 2017. Thermal stability of oils added with avocado (Persea americana cv. Hass) or olive (Olea europaea cv. Arbequina) leaf extracts during the French potatoes frying. Food Chem. 221, 123-129. https://doi.org/10.1016/j.foodchem.2016.10.051

Kalogeropoulos N, Andrikopoulos NK. 2004. Squalene in oils and fats from domestic and commercial frying of potatoes. Int. J. Food Sci. Nutr. 55, 125-129. https://doi.org/10.1080/ 09637480410001666531

Kalogeropoulos N, Tsimidou M. 2014. Antioxidants in Greek virgin olive oils. Antioxidants 3, 387-413. https://doi. org/10.3390/antiox3020387

Kalogianni EP, Georgiou D, Romaidi M, Exarhopoulos S, Petridis D, Karastogiannidou C, Dimitreli G, Karakosta P. 2017. Rapid methods for frying oil quality determination: evaluation with respect to legislation criteria. $J$. Am. Oil Chem. Soc. 94, 19-36. https://doi.org/10.1007/ s11746-016-2919-1

Kochhar SP. 2000. Stabilization of frying oils with natural antioxidative components. Eur. J. Lipid Sci. Technol. 102, 552-559. https://doi.org/10.1002/1438-9312(200009) 102:8/9<552::AID-EJLT552>3.0.CO;2-V

Kochhar SP. 2001. The composition of frying oils, in Frying: Improving Quality. Ed. Rossell JB, Woodhead Publishing, Lancaster, UK, 87-114.

Kochhar SP, Gertz C. 2004. New theoretical and practical aspects of the frying process. Eur. J. Lipid Sci. Technol. 106, 722-727. https://doi.org/10.1002/ejlt.200400996

Lampi A, Kamal-Eldin A. 1998. Effect of $\alpha$ - and $\gamma$ - tocopherols on thermal polymerization of purified high-oleic sunflower triacylglycerols. J. Am. Oil Chem. Soc. 75, 1699-1703. https://doi.org/10.1007/s11746-998-0319-x

Lampi AM, Dimberg LH, Kamal-Eldin A. 1999. A study on the influence of fucosterol on thermal polymerisation of purified high oleic sunflower triacylglycerols. J. Sci. Food Agr. 79, 573-579. https://doi.org/10.1002/(SICI) 1097-0010 (19990315)79:4<573::AID-JSFA219>3.3.CO;2-G

Malecka M. 1991. The effect of squalene on the heat stability of rapeseed oil and model lipids. Nahrung 35, 541-542. https://doi.org/10.1002/food.19910350521

Malecka M. 1994. The effect of squalene on the thermostability of rapeseed oil. Nahrung 38, 135-140. https://doi.org/10.1002/ food.19940380205

Manzi P, Panfili G, Esti M, Pizzoferrato L. 1998. Natural antioxidants in the unsaponifiable fraction of virgin olive oils from different cultivars. J. Sci. Food Agric. 77, 115-120. https:// doi.org/10.1002/(SICI) 1097-0010(199805)77:1<115::AIDJSFA13 $>3.0 . \mathrm{CO} ; 2-\mathrm{N}$

Marmesat S, Mancha M, Ruiz Méndez MV, Dobarganes MC. 2005. Performance of sunflower oil with high levels of oleic and palmitic acids during industrial frying of almonds, peanuts, and sunflower seeds. J. Am. Oil Chem. Soc. 82, 505-510. https://doi.org/10.1007/ s11746-005-1101-6

Marmesat S, Velasco J, Ruiz-Méndez MV, Fernández-Martínez JM, Dobarganes MC. 2008. Thermostability of genetically modified sunflower oils differing in fatty acid and tocopherol compositions. Eur. J. Lipid Sci. Technol. 110, 776-782. https://doi.org/10.1002/ejlt.200800040

Márquez-Ruiz G, Martín-Polvillo M, Jorge N, Ruiz Méndez MV, Dobarganes MC. 1999. Influence of used frying oil quality and natural tocopherol content on oxidative stability of fried potatoes. J. Am. Oil Chem. Soc. 76, 421-425. https://doi.org/10.1007/s11746-999-0019-1

Márquez-Ruiz G, Martín-Polvillo M, Velasco J, Dobarganes MC. 2008. Formation of oxidation compounds in olive and sunflower oils under oxidative stability index (OSI) conditions. Eur. J. Lipid Sci. Technol. 110, 465-471. https:// doi.org/10.1002/ejlt.200700246

Márquez-Ruiz G, Ruiz-Méndez MV, Velasco J. 2014. Antioxidants in frying: analysis and evaluation of efficacy. Eur. J. Lipid Sci. Technol. 116, 1441-1450. https://doi.org/ 10.1002/ejlt.201400063

Márquez-Ruiz G, Ruiz-Méndez MV, Velasco J, Dobarganes MC. 2010. Preventing oxidation during frying of foods, in Oxidation in Foods and Beverages and Antioxidant Applications. Ed. Decker E, Elias R, McClements DJ, Woodhead Publishing, Lancaster, UK, 2; 239- 273.

Martín-Polvillo M, Márquez-Ruiz G, Dobarganes MC. 2004. Oxidative stability of sunflower oils differing in unsaturation degree during long-term storage at room temperature. J. Am. Oil Chem. Soc. 81, 577-583. https://doi.org/10.1007/ s11746-006-0944-1

Mateos R, Espartero JL, Ríos JJ, León-Camacho M, Alcudia F, Cert A. 2001. Determination of phenols, flavones and lignans in virgin olive oils by solid-phase extraction and high-performance liquid chromatography with diode array ultraviolet detection. J. Agric. Food Chem. 49, 2185-2192. https://doi.org/10.1021/jf0013205

Molina-García L, Santos CSP, Cunha SC, Casal S, Fernandes JO. 2017. Comparative fingerprint changes of toxic volatiles in low PUFA vegetable oils under deep-frying. $J$. Am. Oil Chem. Soc. 94, 271-284. https://doi.org/10.1007/ s11746-016-2943-1

Montedoro G, Servili M, Baldioli M, Miniati E. 1992. Simple and hydrolyzable phenolic compounds in virgin olive oil.1. Their extraction, separation, and quantitative and semiquantitative evaluation by HPLC. J. Agric. Food Chem. 40, 1571-1576. https://doi.org/10.1021/jf00021a019

Nergiz C, Celikkale D. 2011. The effect of consecutive steps of refining on squalene content of vegetable oils. $J$. Food Sci. Technol. 48, 382-385. https://doi.org/10.1007/ s13197-010-0190-2

Nissiotis M, Tasioula-Margari M. 2003. Changes in antioxidant concentration of virgin olive oil during thermal oxidation. Food Chem. 77, 371-376. https://doi.org/10.1016/ S0308-8146(02)00113-9

Normand L, Eskin NAM, Przybyslki R. 2001. Effects of tocopherols on the frying stability of regular and modified canola oils. J. Am. Oil Chem. Soc. 78, 369-373. https://doi. org/10.1007/s11746-001-0270-7

Oil World Annual 2017. Volume 1. Ed. Oil World. Independent Global Market Analyses \& Forecasts since 1958. ISTA Mielke GmbH. Hamburg, Germany.

Olivero-David R, Mena C, Pérez-Jimenez MA, Sastre B, Bastida S, Márquez-Ruiz G, Sánchez-Muniz FJ. 2014. Influence of Picual olive ripening on virgin olive oil alteration and stability during potato frying. J. Agric. Food Chem. 62, 11637-11646. https://doi.org/10.1021/jf503860j

Olivero-David R, Mena C, Sánchez-Muniz FJ, Pérez-Jimenez MA, Holgado F, Bastida S, Velasco, J. 2017. Frying performance of two virgin oils from Cornicabra olives with different ripeness indices. Grasas Aceites 68, https://doi. org/10.3989/gya.0666171

Pérez-Camino MC, Cert A. 1999. Quantitative determination of hydroxyl pentacyclic triterpene acids in vegetable oils. J. Agric. Food Chem. 47, 1558-1562. https://doi.org/ $10.1021 / \mathrm{jf} 980881 \mathrm{~h}$

Romano R, Giordano A, Vitiello S, Le Grottaglie L, Spagna Musso S. 2012. Comparison of the frying performance of olive oil and palm superolein. J. Food Sci. 77, 519-531. https://doi.org/10.1111/j.1750-3841.2012.02663.x

Romero A, Cuesta C, Sánchez-Muniz FJ. 1999. Does frequent replenishment with fresh monoenoic oils permit the frying of potatoes indefinitely?. J. Agric. Food Chem. 47, 1168-1173. https://doi.org/10.1021/jf980675+

Ruiz-Méndez MV, Aguirre MR, Marmesat S. 2013. Olive oil refining process, in Handbook of Olive Oil: Analysis and Properties. Ed. Aparicio R, Harwood J, Springer, US, 715-738. https://doi.org/10.1007/978-1-4614-7777-8

Ruiz-Méndez MV, Dobarganes MC, Sánchez-Moral P. 2008. Aceite de orujo de oliva comestible concentrado en ácidos triterpénicos, procedimiento de refinación física utilizado 
para su obtención y recuperación de los componentes funcionales presentes en el aceite crudo. Pat. $\mathrm{N}^{\circ} \mathrm{ES} /$ $\mathrm{P} 2008 / 02178 /-\mathrm{WO} / 2010 / 010219$

Sánchez-Gimeno AC, Negueruela AI, Benito M, Vercet A, Oria R. 2009. Some physical changes in Bajo Aragon extra virgin olive oil during the frying process. Food Chem. 110, 654-658. https://doi.org/10.1016/j.foodchem. 2008.02.057

Santos CSP, Cunha SC, Casal S. 2017. Deep or air frying? A comparative study with different vegetable oils. Eur. J. Lipid Sci. Technol. 119, 1600375. https://doi.org/10.1002/ ejlt.201600375

Santos CSP, Molina-García L, Cunha SC, Casal S. 2018. Fried potatoes: Impact of prolonged frying in monounsaturated oils. Food Chem. 243, 192-201. https://doi.org/10.1016/j. foodchem.2017.09.117

Sims RJ, Fioriti JA, Kanuk MJ. 1972. Sterol additives as polymerization inhibitors for frying oils. J. Am. Oil Chem. Soc. 49, 298-301. https://doi.org/10.1007/BF02637578

Singh A. 2013. Sitosterol as an antioxidant in frying oils. Food Chem. 137, 62-67. https://doi.org/10.1016/j.foodchem.2012.10.008

Steel CJ, Dobarganes MC, Barrera-Arellano D. 2005. The influence of natural tocopherols during thermal oxidation of refined and partially hydrogenated soybean oils. Grasas Aceites 56, 46-52. https://doi.org/10.3989/gya.2005.v56.i1.133

Steel CJ, Dobarganes MC, Barrera-Arellano D. 2006. Formation of polymerization compounds during thermal oxidation of cottonseed oil, partially hydrogenated cottonseed oil and their blends. Grasas Aceites 57, 284-291. https://doi. org/10.3989/gya.2006.v57.i3.50

Tabee E, Jägerstad M, Dutta PC. 2009. Frying quality characteristics of French fries prepared in refined olive oil and palm olein. J. Am. Oil Chem. Soc. 86, 885-893. https://doi. org/10.1007/s11746-009-1417-0

Tekin L, Aday MS, Yilmaz E. 2009. Physicochemical changes in hazelnut, olive pomace, grapeseed and sunflower oils heated at frying temperatures. Food Sci. Technol. Res. 15, 519-524. https://doi.org/10.3136/fstr.15.519

Valdés A, García A. 2006. A study of the evolution of the physicochemical and structural characteristics of olive and sunflower oils after heating at frying temperatures. Food Chem. 98, 214-219. https://doi.org/10.1016/j.foodchem.2005.05.061
Velasco J, Dobarganes MC. 2002. Oxidative stability of virgin olive oil. Eur. J. Lipid Sci. Technol. 104, 661-676. https:// doi.org/10.1002/1438-9312(200210)104:9/10<661::AIDEJLT661>3.0.CO;2-D

Velasco L, Domínguez J, Fernández-Martínez JM. 2004. Registration of T589 and T2100 sunflower germplasms with modified tocopherols. Crop Sci. 44, 361-362.

Verleyen T, Kamal-Eldin A, Mozuraityte R, Verhé R, Dewettinck K, Huyghebaert A, De Greyt W. 2002. Oxidation at elevated temperatures: competition between $\alpha$-tocopherol and unsaturated triacylglycerols. Eur. J. Lipid Sci. Technol. 104, 228-233. https://doi.org/10.1002/1438-9312(200204)104:4<228::AIDEJLT228>3.0.CO;2-5

Visioli F, Bellomo G, Galli C. 1998. Free radical-scavenging properties of olive oils polyphenols. Biochem. Biophys. Res. Commun. 247, 60-64. https://doi.org/10.1006/bbrc. 1998.8735

Warner K, Fehr W. 2008. Mid-oleic/ultra low linolenic acid soybean oil: A healthful new alternative to hydrogenated oil for frying. J. Am. Oil Chem. Soc. 85, 945-951. https://doi. org/10.1007/s11746-008-1275-1

Warner K, Moser J. 2009. Frying stability of purified mid-oleic sunflower oil triacylglycerols with added pure tocopherols and tocopherol mixtures. J. Am. O"il'. Soc. 86, 1199-1207. https://doi.org/10.1007/s11746-009-1461-9

White P. 2008. Fatty acids in oilseeds (vegetable oils), in Fatty Acids in Foods and Their Health Implications. Ed. Kuang Chow, CRC Press Taylor and Francis, Boca Raton, US, 227-262.

Wrinkler JK, Warner K. 2008. The effect of phytosterol structure on thermal polymerization of heated soybean oil. Eur. J. Lipid Sci. Technol. 110, 1068-1077. https://doi.org/10.1002/ ejlt.200800089

Yuki E, Ishikawa Y. 1976. Tocopherol contents of 9 vegetable frying oils, and their changes under simulated deep-fat frying conditions. J. Am. Oil Chem. Soc. 53, 673-676. https://doi.org/10.1007/BF02586335

Zribi A, Jabeur H, Aladedunye F, Rebai A, Matthäus B, Bouaziz M. 2014. Monitoring of quality and stability characteristics and fatty acid compositions of refined olive and seed oils during repeated pan- and deep-frying using GC, FT-NIRS, and chemometrics. J. Agric. Food Chem. 62, 10357-10367. https://doi.org/10.1021/jf503146f 